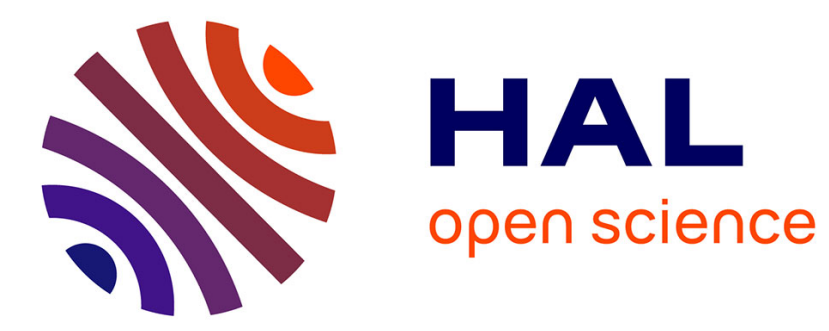

\title{
Measurement and prediction of solar radiation distribution in full-scale greenhouse tunnels
}

\author{
Shaojin Wang, Thierry Boulard
}

\section{To cite this version:}

Shaojin Wang, Thierry Boulard. Measurement and prediction of solar radiation distribution in fullscale greenhouse tunnels. Agronomie, 2000, 20 (1), pp.41-50. 10.1051/agro:2000107 . hal-00885992

\section{HAL Id: hal-00885992 \\ https://hal.science/hal-00885992}

Submitted on 1 Jan 2000

HAL is a multi-disciplinary open access archive for the deposit and dissemination of scientific research documents, whether they are published or not. The documents may come from teaching and research institutions in France or abroad, or from public or private research centers.
L'archive ouverte pluridisciplinaire HAL, est destinée au dépôt et à la diffusion de documents scientifiques de niveau recherche, publiés ou non, émanant des établissements d'enseignement et de recherche français ou étrangers, des laboratoires publics ou privés. 


\title{
Measurement and prediction of solar radiation distribution in full-scale greenhouse tunnels
}

\author{
Shaojin WANG, Thierry BoulaRD* \\ Unité de Bioclimatologie, INRA, Site Agroparc, Domaine Saint-Paul, 84914 Avignon Cedex 9, France
}

(Received 20 July 1999; accepted 18 November 1999)

\begin{abstract}
Radiative heterogeneity in greenhouses significantly influences crop activity, particularly transpiration and photosynthesis. This is especially true for plastic tunnels, which are the most commonly used greenhouse type in the Mediterranean basin. A computer model was generated for this study based on sun movement, greenhouse geometry, transmittance of the cover and weather conditions. Experiments to test model accuracy were performed in a standard $8 \mathrm{~m}$ wide east-west orientated lettuce tunnel located near Avignon (southern France). Solar radiation distribution was studied using 32 solar cells placed on the soil surface along 4 sections situated either in the tunnel centre or near the west gable end. Measured and simulated data of transmittance were close together for both cloudy and clear sky weather conditions. The tested model was then used to simulate solar radiation intensity distribution at the soil level in various tunnel types for different periods of the year. Simulated results revealed high radiative heterogeneity in tunnels, mainly due to effects of gable ends, vent openings and frames. Statistical analysis indicated that solar radiation inside the greenhouse at ground level was higher in the N-S orientated tunnel than in the E-W orientated tunnel in March and June, but radiative heterogeneity was higher in the N-S orientated tunnel, especially in June. Transversal heterogeneity in the E-W orientated tunnel was much higher than longitudinal heterogeneity. Global heterogeneity increased from March to June for both tunnel positions although its relative value remained approximately unchanged.
\end{abstract}

\section{Greenhouse tunnel / radiative heterogeneity / computer model / simulation}

Résumé - Mesure et simulation de la distribution du rayonnement solaire dans les serres tunnels. L'hétérogénéité radiative sous serre influence fortement l'activité du couvert et plus particulièrement la photosynthèse et la transpiration. En ce qui concerne le tunnel, le type de serre le plus répandu dans la région méditerranéenne, l'absence de données expérimentales ainsi que la complexité des échanges radiatifs expliquent pourquoi la répartition fine du climat radiatif demeure mal connue et pourquoi elle est rarement prise en compte dans les modèles de simulation numérique. Dans cette étude, un modèle informatique de transfert radiatif sous tunnel a été développé. Il tient compte de la position du soleil dans le ciel, de la géométrie du couvert et de la présence d'ouvertures, de la présence de structures et de petits bois

Communicated by Gérard Guyot (Avignon, France)

* Correspondence and reprints

boulard@avignon.inra.fr 
et enfin de la répartition du rayonnement incident en rayonnement direct et diffus. On a procédé à une validation de ce modèle dans un tunnel de $8 \mathrm{~m}$ de laitues situé à Avignon dans le sud de la France. La distribution du rayonnement solaire à la surface du sol a été mesurée à l'aide de 32 cellules solaires disposées selon 4 sections situées soit au centre du tunnel, soit à proximité du pignon ouest du tunnel. La comparaison entre les valeurs mesurées et calculées montre que le modèle fonctionne convenablement, à la fois les jours couverts et ensoleillés. Le modèle ayant été validé de façon satisfaisante, il a ensuite été utilisé pour simuler la répartition spatiale du rayonnement à la surface du sol, pour différentes orientations et pendants différentes périodes de l'année. On a mis ainsi en évidence une forte hétérogénéité spatiale qui était liée à la forme du tunnel et surtout à la présence d'ouvrants et d'ombres portées par les structures.

\section{Serre tunnel / hétérogénéité radiative / modèles / simulation}

\section{Introduction}

Solar radiation distribution in greenhouses is an important factor influencing crop transpiration and photosynthesis. It is highly dependent on greenhouse design, radiative capacity of the covering material and weather conditions. Radiative heterogeneity is particularly important in tunnel greenhouses, the most commonly used greenhouse type in the Mediterranean basin. This variability severely effects plant activity and often leads growers to over fertilize, as has been observed for lettuce crops [6].

A number of experimental and theoretical studies on solar transmittance in different greenhouse types have already been performed. Spectral properties of several greenhouse cover materials have been measured both in laboratory [12] and field conditions [7]. Solar radiation transmittance of a single span greenhouse has also been investigated experimentally using a scale model [13]. Modelling solar radiation transmittance was carried out in early 1970s. Smith and Kingham [14] computed direct and hemispherical radiation transmittance by evaluating the fraction of ground area irradiated by a transmitted beam and Kozai and his co-workers $[8,9]$ performed a study on radiation transmittance in single and multi-span greenhouses. Their model ignores all reflected light and effects of polarisation. But later Thomas [15] studied the effect of a speculatively reflecting material on the north wall of an E-W single span greenhouse. His model accounts a sophisticated method of ray tracing. Amsen [1] established an interesting technique of projecting light-obstructing areas on to a hemisphere, to calculate the light loss to the crop under diffuse light conditions. A series of predictions for solar transmittance in east-west (E-W) and north-south (N-S) orientated greenhouses have been generated using computer modelling at United Kingdom latitudes [2-4]. Solar radiation distributions in either single or multi-span plastic tunnels are much less well understood although Kurata et al. [10] and de Tourdonnet [6] have made some headway. However, no results have been reported on solar radiation distribution in full-scale tunnels with vent openings, side walls and gable end effects.

The objectives of this study were to generate a computer model to simulate radiative heterogeneity at the greenhouse floor level as a function of greenhouse geometry, covering material and weather conditions. Solar radiation distribution at the greenhouse floor level was defined using both measurements and simulations to demonstrate the theoretical model's accuracy and to compare results with simulations performed for different tunnel orientations and covering materials. Simulation results were first experimentally tested based on solar radiation measurements using 32 solar cells at the soil surface along 4 vertical sections, either in the tunnel centre or near the west gable end. The validated model was then used to map radiative heterogeneity in both E-W and N-S orientated tunnels under different typical radiative conditions during various periods of the year near Avignon (latitude: $44^{\circ} \mathrm{N}$, southern France). 


\section{Computer model}

Modelling solar radiation transmittance in a plastic tunnel is a very complicated task due to the influence of covering material, greenhouse structure (frames, vent openings, side walls and gable ends) and weather conditions. To simplify the model, continuous curved surfaces of the arched tunnel were approximated using a finite number of small flat planes. Secondary reflections from inner cover surfaces and soil surface were omitted. Global solar radiation transmitted through a given surface $\left(A^{\prime} B^{\prime} C^{\prime} D^{\prime}\right)$ with a slope angle $\beta$ in $\operatorname{rad}[11]$ was then calculated and projected as a "shadow area" (ABCD) on the soil surface (Fig. 1):

$$
S_{g}\left(x^{\prime}, y^{\prime}, z^{\prime}\right)=\tau_{D} \cdot S_{D}+\tau_{d} S_{d} \cdot \frac{1+\cos \beta}{2}
$$

with

$$
S_{D}=S_{g}-S_{d}
$$

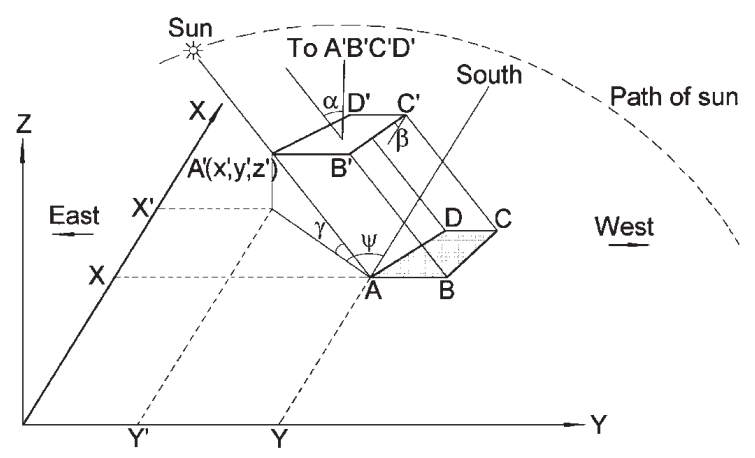

Figure 1. Definition of angles related to the sun's position and schematic illustration of solar radiation transmitted and reaching on the soil surface $(\alpha$ : incidence angle of the area $\mathrm{A}^{\prime} \mathrm{B}^{\prime} \mathrm{C}^{\prime} \mathrm{D}$ '; $\beta$ : slope angle of the surface; $\gamma$ : solar altitude angle; $\psi$ : solar azimuth). where $x^{\prime}, y^{\prime}$ and $z^{\prime}$ are the Cartesian co-ordinates for positions on the cover surface, $S_{d}$ and $S_{D}$ are external diffuse and direct solar radiations $\left(\mathrm{W} \cdot \mathrm{m}^{-2}\right)$, $\mathrm{S}_{\mathrm{g}}$ and $\mathrm{S}_{\mathrm{g}}\left(\mathrm{x}^{\prime}, \mathrm{y}^{\prime}, \mathrm{z}^{\prime}\right)$ are external and internal global solar radiations $\left(\mathrm{W} \cdot \mathrm{m}^{-2}\right), \tau_{\mathrm{d}}$ and $\tau_{\mathrm{D}}$ are diffuse solar and direct transmittances of the tunnel's elementary surface $\left(A^{\prime} B^{\prime} C^{\prime} D^{\prime}\right)$.

To further simplify the model, it was assumed that radiation transmittance was zero for tunnel frames and 1 for vent openings. The experimental value of the transmittance of the plastic cover used in this study was a function of incidence angle $\alpha$ in rad of radiation determined by Nijskens et al. [12]. Transmittance values of $0.69,0.64,0.62,0.59,0.29$ and 0 for direct solar radiation at incidence angles of $0^{\circ}, 15^{\circ}, 30^{\circ}, 45^{\circ}, 60^{\circ} 75^{\circ}$ and $90^{\circ}$ with 0.69 for diffuse solar radiation were used in this study. The actual direct solar transmittance as a function of the incidence angle was linearly interpolated. This incidence angle for a surface is given by de Halleux [5] and Kurata et al. [10] as follows:

$$
\alpha=\arccos [\cos \gamma \cos (\theta-\psi) \sin \gamma \cos \beta]
$$

where $\gamma(\mathrm{rad})$ is solar altitude angle, $\psi(\mathrm{rad})$ is solar azimuth and $\theta$ (rad) is orientation angle of each of the cover's elementary planes relative to $\mathrm{S}-\mathrm{N}$ axis. If the co-ordinate system is assumed to originate from the north-east corner of the tunnel, a solar beam transmitted by the cover from position $\mathrm{A}^{\prime}\left(\mathrm{x}^{\prime}\right.$, $\left.\mathrm{y}^{\prime}, \mathrm{z}^{\prime}\right)$ reaches position $\mathrm{A}(\mathrm{x}, \mathrm{y})$ on the soil surface. For each position on the level of the cover ( $x^{\prime}, y^{\prime}$, $\left.z^{\prime}\right)$ and for each solar position $(\gamma$ and $\psi$ ), the $x$ and y co-ordinates can be determined as follows:

$$
\begin{aligned}
& x=x^{\prime}+z^{\prime} \cos \psi / \operatorname{tg} \gamma \\
& y=y^{\prime}-z^{\prime} \sin \psi / \operatorname{tg} \gamma .
\end{aligned}
$$

It should be pointed out that the direct solar radiation was not calculated if the tunnel cover's elements were projected outside the greenhouse but the diffuse solar radiation was still taken into account. A computer model in Quick Basic was derived from relationships (1) to (5). The main steps of the algorithm are as follows:

1) Initialization of the date, solar time, tunnel location and orientation along together with the coordinates of each of the cover's elementary planes ( $\left.\mathrm{A}^{\prime} \mathrm{B}^{\prime} \mathrm{C}^{\prime} \mathrm{D}^{\prime}\right)$; 
2) Calculation of solar height $\gamma$ and azimuth $\psi$;

3) Calculation of slope $\beta$ and orientation $\theta$, angles for each of the tunnel cover's elementary planes;

4) Determination of the incidence angle of direct solar radiation $\alpha$, using relationship (3) for each of the cover's elementary planes;

5) Computation of internal global solar radiation $\mathrm{S}_{\mathrm{g}}\left(\mathrm{x}^{\prime}, \mathrm{y}^{\prime}, \mathrm{z}^{\prime}\right)$ for each of the cover's elementary planes using relationship (1);

6) Determination of the "shadow area" projected by each of the cover's elementary planes on the tunnel's soil surface using relationships (4) and (5);

7) Calculation of averaged daily global solar radiation by integrating and averaging daily solar radiation received at a given position on the soil surface. Finally, average daily transmittance of global solar radiation was deduced for each position using the ratio of daily integral global solar radiation on the soil surface in the tunnel to outside radiation.

\section{Experimental design}

\subsection{Site and tunnel description}

Measurements were conducted in a standard $8 \mathrm{~m}$ wide $\mathrm{E}-\mathrm{W}$ orientated lettuce tunnel situated near Avignon in southern France ( $44^{\circ}$ latitude). Tunnel dimensions were $8 \times 60 \mathrm{~m}$ with a top height of $3.1 \mathrm{~m}$. Traditional discontinuous vent openings were included. They were formed by separating plastic sheets using $0.4 \mathrm{~m}$ long pieces of wood placed every two meters along both sides of the tunnel. A layout of the tunnel illustrating vent openings is shown in Figure 2.

\subsection{Measurement instruments}

Solar radiation distributions were measured using 32 silicon solar cells set up along four sections in the middle of the tunnel or near the west gable end (Fig. 2). Extensive tests were performed prior to using these solar cells to check that output signals were in line with solar radiation.

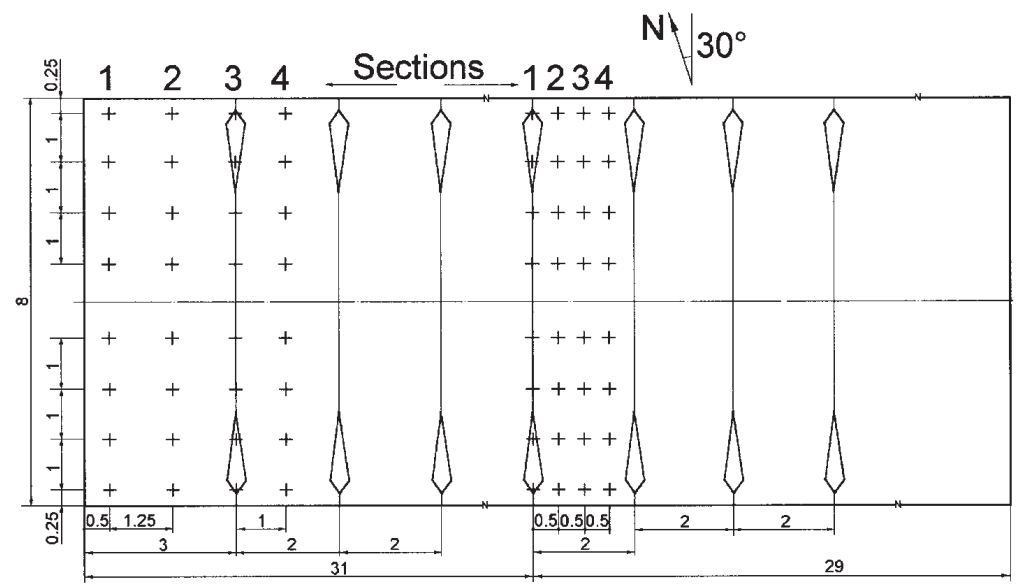

Figure 2. Layout of 32 experimental solar cells (+) distributed in the tunnel centre or near the west wall (all dimensions are in $\mathrm{m}$ ). 
Calibration was performed by comparing a quantum sensor LI-200SB and a pyranometer under different weather conditions. Linear relationships between each solar cell and the quantum sensor were derived which were later used to correct solar radiation distribution measurements. During measuring, external global and diffuse solar radiations were also recorded near the tunnel using pyranometers attached to a $3 \mathrm{~m}$ high mast. All measurements were taken every $10 \mathrm{~s}$ and averaged on-line over 10 minutes then stored in a portable data logger (DELTA-T, Cambridge, UK).

\section{Results and analysis}

\subsection{Model accuracy}

Measurements and simulations were first compared based on measurements taken from the tunnel's center. Validation was performed over four days under both cloudy (February 24 and March 4, 1999) and sunny (February 25 and March 7, 1999) conditions (Fig. 3). Outside global and diffuse solar radiations were used as input parameters for the computer model. An example of average daily transmittances of global solar radiation obtained through experiments and simulations along four sections situated in the tunnel center under a cloudy condition is shown in Figure 4. Measured transmittance in the section situated below the vent opening (Sect. 1) was higher due to vent opening (Fig. 4a) and much lower near the south and north borders due to larger incidence angles. On average, transmittance variation data as a function of tunnel width was similar whether obtained through experiments or simulations. However, an underestimation of simulated transmittance in the north part of the tunnel was observed. Similar results were obtained for Sections 2, 3 and 4. However, no differences in transmittance were detected for locations on the south side just below the openings (Sect. 1) or at similar positions situated between two successive openings below the cover (Sect. 3). Larger discrepancies were found on the north side (Figs. 4 and 5), probably because secondary reflectance on the north inner cover surfaces was

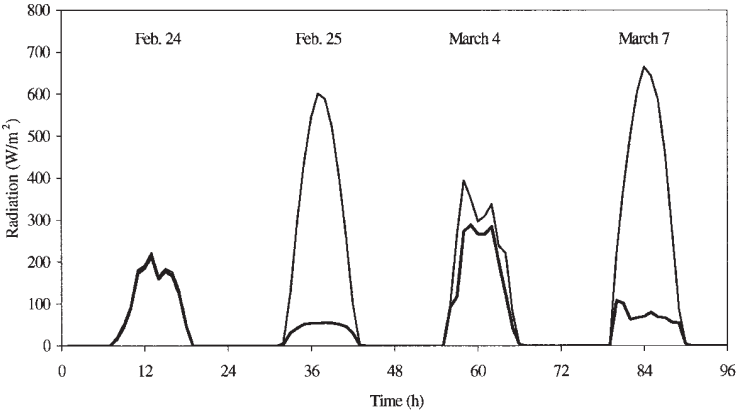

Figure 3. Outside global (-) and diffuse (-) solar radiation under cloudy and clear skies during measurements.
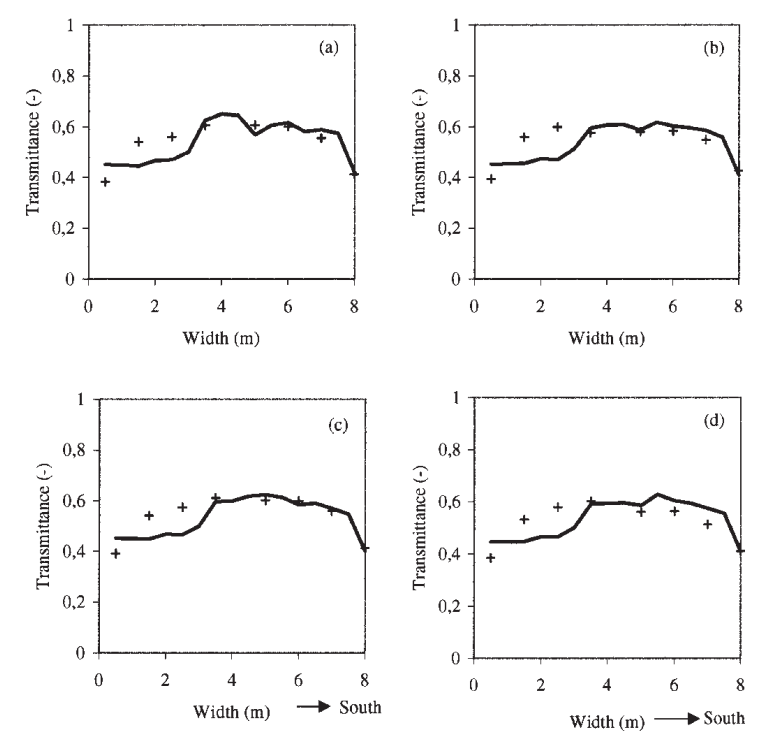

Figure 4. Measured (+) and calculated ( - ) daily averaged transmittances of global solar radiation in the tunnel centre along Sections 1 (a), 2 (b), 3 (c) and 4 (d) under cloudy weather conditions (Feb. 24).

omitted in simulations. This secondary reflectance yielded an important effect as the inner surface of the north side, which was shaped like a parabolic mirror, focused reflected solar radiation on the tunnel soil surface near the north wall. 

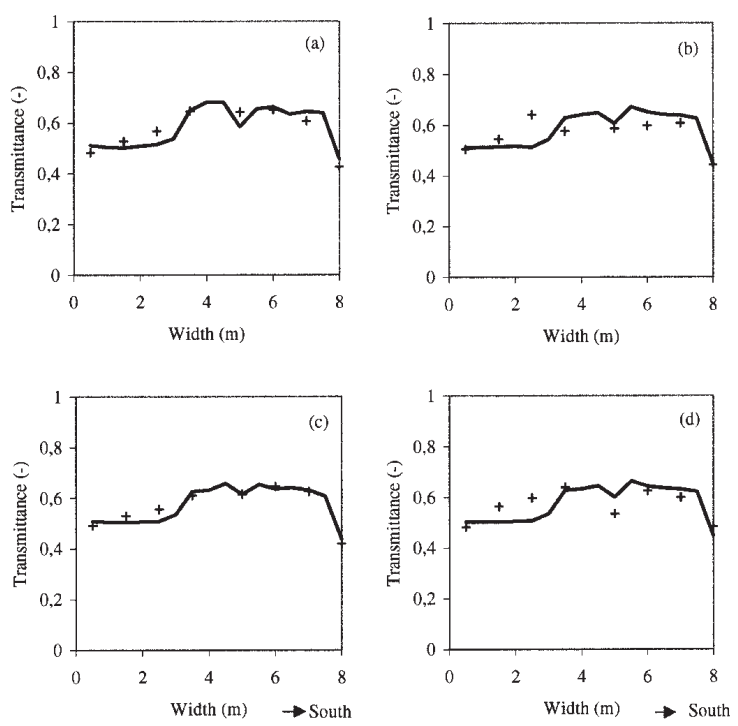

Figure 5. Measured (+) and calculated (-) daily averaged transmittances of global solar radiation in the tunnel centre along Sections 1 (a), 2 (b), 3 (c) and 4 (d) under clear weather conditions (Feb. 25).

Average daily transmittances in the tunnel center under a clear sky are shown in Figure 5. Transmittance patterns obtained both through experiments and simulations were generally similar to results for cloudy skies. Nevertheless, statistical analysis revealed (Tab. 1) a substantial increase in average solar transmittance under clear skies compared to cloudy conditions in all sections. This increase represented about $3.5 \%$ for the measured values and $4.7 \%$ for the simulations.

Figures 6 and 7 show average daily transmittances near the west gable end of the tunnel under cloudy and clear skies respectively. In both cases, transmittance was much lower than in the tunnel center, mainly due to the effects of the side wall and gable ends, particularly in the afternoon. Transmittance in the middle of Section 1 was higher than in all the other sections due to door opening ( $2 \mathrm{~m}$ wide and $1.8 \mathrm{~m}$ high) during the diurnal period. Generally, agreement between the computed and measured transmittances near the gable end was good in all sections under both cloudy and clear weather conditions (Figs. 6 and 7). Table II
Table 1. Averaged transmittances in tunnel centre.

\begin{tabular}{lcccc}
\hline Sections & $\begin{array}{c}\text { Cloudy conditions } \\
\text { (Feb. 24) }\end{array}$ & \multicolumn{2}{c}{$\begin{array}{c}\text { Sunny conditions } \\
\text { (Feb. 25) }\end{array}$} \\
\hline \multicolumn{4}{c}{ Measurement Simulation } & Measurement Simulation \\
\hline 1 & 0.53 & 0.54 & 0.57 & 0.59 \\
2 & 0.53 & 0.54 & 0.56 & 0.58 \\
3 & 0.54 & 0.53 & 0.56 & 0.58 \\
4 & 0.52 & 0.53 & 0.57 & 0.58 \\
Mean & 0.53 & 0.54 & 0.56 & 0.58 \\
\hline
\end{tabular}
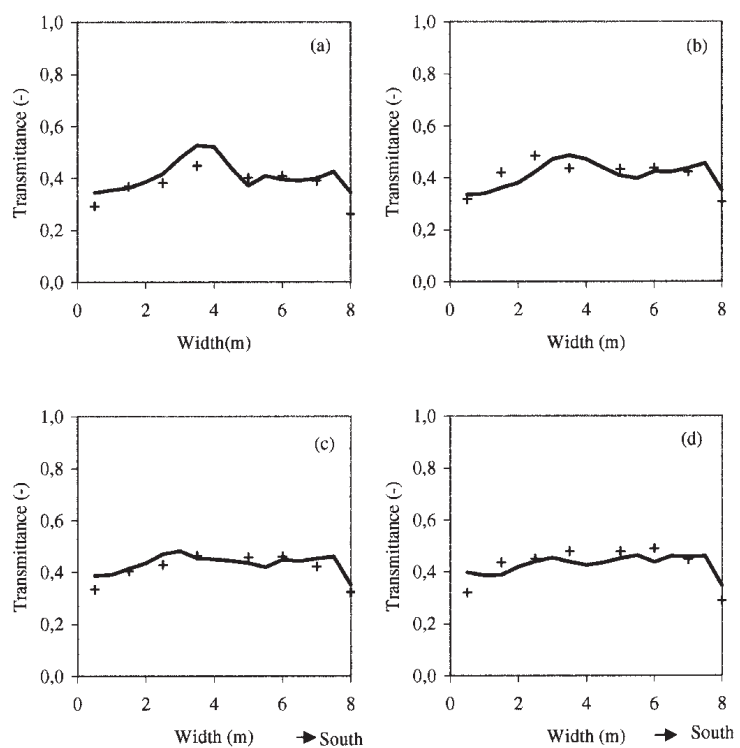

Figure 6. Measured (+) and calculated ( - ) daily averaged transmittances of global solar radiation near the tunnel west wall along Sections 1 (a), 2 (b), 3 (c) and 4 (d) under cloudy weather conditions (March 4).

shows average measured and simulated transmittances during cloudy (0.40 compared to 0.42 ) and sunny days ( 0.46 compared to 0.49 ).

Table II shows that transmittance loss near the gable end was very high: $13 \%$ during cloudy days, 
Table 2. Averaged transmittances near tunnel side wall.

\begin{tabular}{lcccc}
\hline Sections & $\begin{array}{c}\text { Cloudy conditions } \\
\text { (March 4) }\end{array}$ & \multicolumn{2}{c}{$\begin{array}{c}\text { Sunny conditions } \\
\text { (March 7) }\end{array}$} \\
& \multicolumn{3}{c}{ Measurement Simulation Measurement Simulation } \\
\hline 1 & 0.37 & 0.41 & 0.43 & 0.47 \\
2 & 0.41 & 0.41 & 0.46 & 0.50 \\
3 & 0.41 & 0.43 & 0.46 & 0.49 \\
4 & 0.42 & 0.43 & 0.48 & 0.50 \\
Mean & 0.40 & 0.42 & 0.46 & 0.49 \\
\hline
\end{tabular}
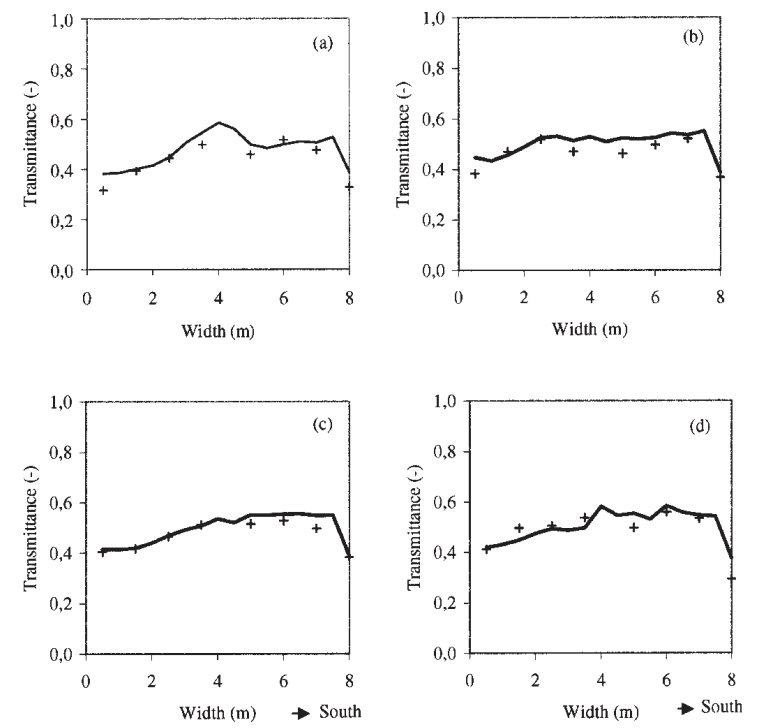

Figure 7. Measured (+) and calculated ( - ) daily averaged transmittances of global solar radiation near the tunnel west wall along Sections 1 (a), 2 (b), 3 (c) and 4 (d) under clear weather conditions (March 7).

$10 \%$ during sunny days. However, this value was slightly smaller than transmittance loss (16\%) observed between the middle of the tunnel and the sides when transversal heterogeneity was considered.

\subsection{Model application}

Once the computer model was validated in the tunnel centre and near the gable end under both cloudy and clear conditions, it could reasonably and reliably be used to predict solar radiation distribution in similar tunnel types with different orientations at different seasons in Avignon latitude. This simulated tunnel $\left(22 \times 8 \mathrm{~m}^{2}\right)$ was assumed to be equipped with discontinuous vent openings made by separating plastic sheets every four meters using $0.6 \mathrm{~m}$ long pieces of wood. As in experiments, total daily radiation received at each point on the soil surface was added together then averaged out over the length of the diurnal period.

Figure 8 illustrates global solar radiation distribution over the ground surface of full-scale E-W and N-S orientated tunnels on March 21. Considerable variations in global solar radiation between both tunnels were observed. For both orientations, higher solar radiation values at the soil surface were due to higher radiative transmittance through the vent openings while lower values were caused by lower transmittance due to larger solar radiation incidence angles. Due to the sun's lower position, the largest heterogeneity was observed along the transversal section of the E-W orientated tunnel. Solar radiation distribution in the N-S orientated tunnel was nearly symmetrical along the tunnel axis and average transmittance was slightly higher than in the E-W orientated tunnel. However, higher contrasts were found between areas situated below vent openings and in the center, characterized by high transmittance, and zones situated along the sides and gable ends associated with lower transmittance.

Solar radiation distributions over the ground surface in both E-W and N-S orientated tunnels on June 21 are shown in Figure 9. A side wall effect can be observed in the E-W orientated tunnel on both the south side and the two gable ends. Average distribution of solar radiation was more homogeneous than in N-S orientated tunnels. Higher solar radiation values were observed in the center of the N-S orientated tunnel during summer due to a relatively smaller solar radiation angle of incidence in the top part of the cover. Higher 


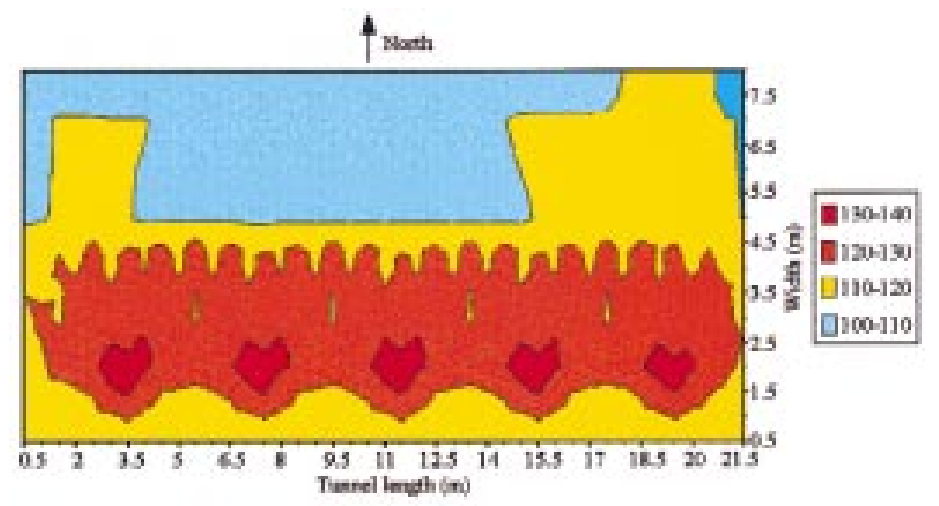

(a)

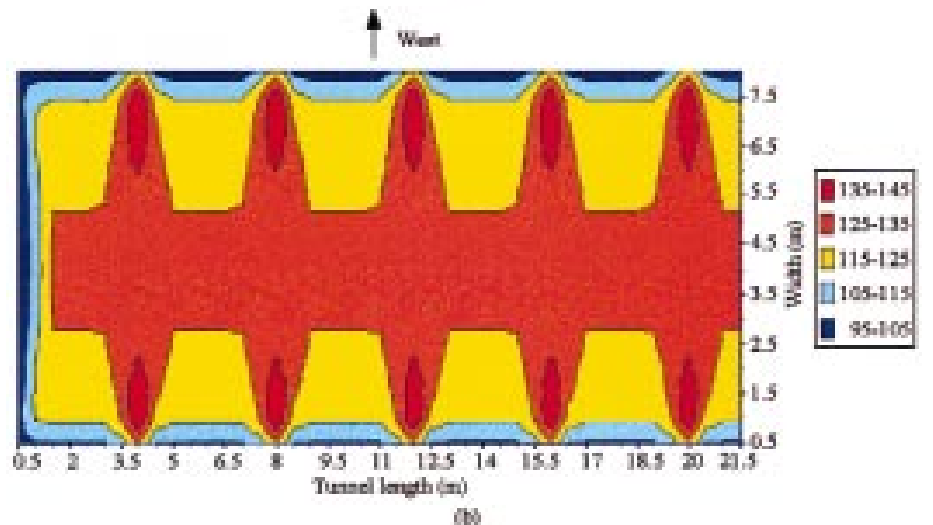

Figure 8. Simulated average solar radiation distributions in E-W (a) and N-S (b) orientated tunnels on March 21 (Outside average solar radiation was $\left.196 \mathrm{~W} \cdot \mathrm{m}^{-2}\right)$.

Table 3. Statistical results of global solar radiation $\left(\mathrm{W} \cdot \mathrm{m}^{-2}\right)$ distributions in E-W and N-S orientated tunnels on March 21 and June 21.

\begin{tabular}{lcccccccc}
\hline \multirow{2}{*}{ Tunnels } & Date & \multicolumn{2}{c}{ Mean } & Min. & Max. & \multicolumn{2}{c}{$\begin{array}{c}\text { Standard deviation } \\
\text { Longitudinal }\end{array}$} \\
& & Outside & Inside & & & Global & (ransversal \\
\hline E-W & March 21 & 196 & 115.9 & 101.9 & 134.3 & 7.7 & 1.5 & 7.2 \\
& June 21 & 465 & 282.8 & 238.0 & 31.7 & 13.4 & 6.4 & 10.9 \\
N-S & March 21 & 196 & 121.9 & 94.7 & 146.4 & 9.8 & 6.4 & 6.7 \\
& June 21 & 465 & 289.6 & 246.8 & 331.6 & 18.2 & 12.8 & 11.5 \\
\hline
\end{tabular}

values were also found for the same orientation below the vent openings where radiation penetration was heightened by the absence of a plastic cover.

Statistical analysis of radiative heterogeneity was performed both on March 21 and June 21 by comparing average values and standard deviations (for the E-W and N-S orientated tunnels: Tab. III). If $\mathrm{x}$ and $\mathrm{y}$ represent respectively transversal and longitudinal directions at the soil surface, three different standard deviations can be calculated: global, $\sigma_{x, \mathrm{y}}$; transversal, $\sigma_{x, \overline{\mathrm{y}}}$ and longitudinal, $\sigma_{\overline{\mathrm{x}}, \mathrm{y}}$. 


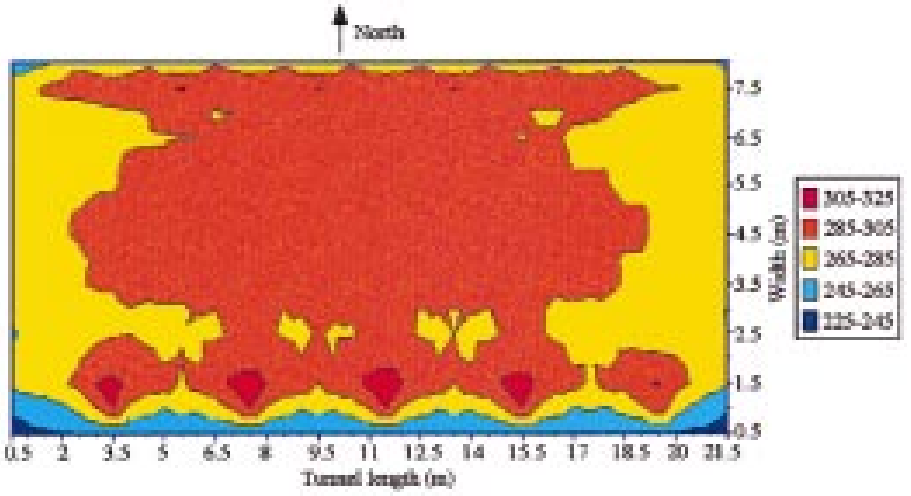

(a)

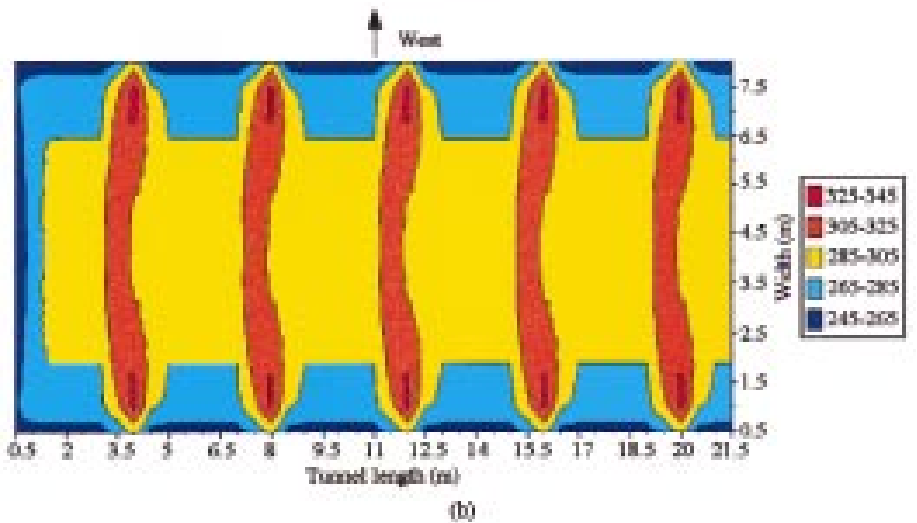

Figure 9. Simulated average solar radiation distributions in E-W (a) and N-S (b) orientated tunnels on June 21 (outside average solar radiation was $465 \mathrm{~W} \cdot \mathrm{m}^{-2}$ ).

Solar radiation in the N-S orientated tunnel was higher than in the E-W orientated tunnel in March and June. This difference was low in March (5\%) and June (2\%). Conversely, radiative heterogeneity was higher in the N-S orientated tunnel than in the E-W orientated tunnel, especially in June. Generally, global heterogeneity $\left(\sigma_{x, y}\right)$ increased from March to June for both orientations, although its relative value $\left(\sigma_{x, y} / S_{g}(x, y)\right)$ remained approximately unchanged. Transversal heterogeneity in March $\left(\sigma_{x, \bar{y}}=7.2 \mathrm{~W} \cdot \mathrm{m}^{-2}\right)$ in the E-W orientated tunnel was much higher than longitudinal heterogeneity $\left(\sigma_{\bar{x}, y}=1.5 \mathrm{~W} \cdot \mathrm{m}^{-2}\right)$. However, transversal and longitudinal heterogeneities were nearly the same for both March (6.4 and 6.7) and June (12.8 and 11.5) in simulations for the N-S orientated tunnel.

\section{Conclusions}

As radiative heterogeneity in greenhouses is crucial for both crop transpiration and photosynthesis, a computer model to calculate solar radiation distribution based on greenhouse structure, surface transmittances and solar positions was generated. Predicted results of solar transmittances were validated through comparison with experimental values obtained using 32 solar cells in a full-scale E-W orientated tunnel in February and March. Simulated transmittance variations over tunnel width concurred with experimental results both under cloudy and clear weather conditions. However a slight underestimation was observed for the north side of the tunnel as secondary 
reflectance on the inner surface of the north side cover was omitted.

The validated computer model was applied to map solar radiation heterogeneity in E-W and N-S orientated tunnels in Avignon on March 21 and June 21. The results revealed considerable variations in global solar radiation over the tunnel ground surface. These variations were mainly caused by vent openings, gable ends and different incidence angles for various cover surfaces. Transmittance for the N-S orientated tunnel was slightly higher than for the E-W tunnel. The E-W orientated tunnel was primarily marked by a N-S gradient, resulting in moderate global radiative heterogeneity. Heterogeneity in the N-S orientated tunnel was higher, but more evenly distributed in all directions.

Acknowledgements: The authors wish to express their deepest thanks to J.C. L'Hotel for his technical support with the measurement system and M. Keller for providing us with the measurement site in a greenhouse at the "Lycée Agricole de Cantarel" in Avignon.

\section{References}

[1] Amsen M.G., A simple method to calculate improvements of diffuse light distribution in detached greenhouses, Acta Hort. 174 (1985) 105-109.

[2] Critten D.L., The evaluation of a computer model to calculate the daily light integral and transmissivity of a greenhouse, J. Agric. Eng. Res. 28 (1983) 545-563.

[3] Critten D.L., The prediction of multi-span greenhouse light transmittance with particular reference to tunnels under direct winter light conditions, J. Agric. Eng. Res. 38 (1987) 57-64.

[4] Critten D.L., Direct sunlight losses in north-south aligned multi-span greenhouses with symmetric roofs at UK latitudes, J. Agric. Eng. Res. 40 (1988) 71-79.
[5] De Halleux D., Modèle dynamique des échanges énergétiques des serres : étude théorique et expérimentale, Ph.D. thesis, Faculté des Sciences Agronomiques de Gembloux, Belgique, 1989, pp. 105-220.

[6] De Tourdonnet S., Maîtrise de la qualité et de la pollution nitrique en production de laitues sous abris plastique : diagnostique et modélisation des effets des systèmes de culture, Thèse de Doctorat de l'INRA ParisGrignon, 1998, pp. 10-225.

[7] Kittas C., Baille A., Determination of the spectral properties of several greenhouse cover materials and evaluation of specific parameters related to plant response, J. Agric. Eng. Res. 71 (1998) 193-202.

[8] Kozai T., Direct solar light transmission into single-span greenhouses, Agric. Meteorol. 18 (1977) 327-338.

[9] Kozai T., Kimura M., Direct solar light transmission into multispan greenhouses, Agric. Meteorol. 18 (1977) 339-349.

[10] Kurata K., Quan Z., Nunomura O., Optimal shapes of parallel east-west oriented single span tunnels with respect to direct light transmissivity, J. Agric. Eng. Res. 48 (1991) 89-100.

[11] Lunde P.J., Solar thermal engineering: space heating and hot water systems, John Wiley \& Sons, New York, 1980, pp. 612.

[12] Nijskens J., Deltour J., Coutisse S., Nisen A., Radiation transfer through covering materials, solar and thermal screens of greenhouses, Agric. For. Meteorol. 35 (1985) 229-242.

[13] Papadakis G., Manolakos D., Kyritsis S., Solar radiation transmissivity of a single span greenhouse through measurements on scale models, J. Agric. Eng. Res. 71 (1998) 331-338.

[14] Smith C.V., Kingham H.G., A contribution to glasshouse design, Agric. Meteorol. 8 (1971) 447.

[15] Thomas R.B., The use of speculatively reflecting back walls in greenhouses, J. Agric. Eng. Res. 23 (1978) 85-97. 